\title{
Japan's Position in the Context of Agricultural Trade Issues
}

\author{
Shinichi Shogenji ${ }^{1}$
}

\begin{abstract}
Agriculture and food in Japan have characteristics of a newly developed country. In addition, its trade in agricultural products differs from that of developed countries on new continents or the EU, depending largely on the food and feed imported from abroad. Long-term analysis of these characteristics will be especially useful for further development of Monsoon Asian countries. Japan's agricultural trade policy reflects two viewpoints which differ from the classical theory of free trade. One is concern about food security and the other is respect for multi-functional roles of agriculture. Regarding food security, we should be careful about the difference between the concept in developed countries and developing countries. Multi-functionality can commonly be respected among EU and Asian countries; both have a long history of rural areas. Taking into consideration international income disparity, there is some concern about the FTA and EPA system.
\end{abstract}

Key words: newly developed country, Monsoon Asia, food security, multi-functional roles of agriculture

\section{Introduction}

The Doha Round has long been on the rocks. The biggest factor is that the conflicts between developed and developing countries over various themes cannot be resolved. The multilateral negotiation, named formally the Doha Development Agenda, places importance on considerations for developing countries. It is somewhat ironic that the stalemate cannot be broken because developing countries have increasingly powerful voices. The Ministerial Declaration states, "The majority of WTO members are developing countries. We seek to place their needs and interests at the heart of the Work Programme adopted in this Declaration". Such a stance by the WTO still has not lost its importance in considering future trade negotiations including agricultural products.

This paper discusses how research into agricultural economics can contribute to the creation of international rules for future agricultural trade taking into consideration the current framework of the WTO, which has in its scope the issues of developing countries. The author's past research mainly focused on Japanese agriculture and food, with occasional reference to EU and Japanese agricultural policy. Hence, the paper firstly gives an overview of the position of Japanese agriculture and food from a rather long-term viewpoint. Then it briefly looks back on the postwar history of how the Japanese government dealt with issues of agricultural trade. Based on these, the author gives his view on the appropriate form of agricultural trade negotiations with basic theory of trade in mind. The point is to explore the possibility of applying the framework of the role of a market economy and that of the government to the international community.

The history of Japanese agriculture, food and trade negotiations may contain informative points for other countries, especially for Monsoon Asia, on how they deal with agricultural trade. Among them, those countries that are at the initial stage of economic growth may find useful elements in the experiences of Japan. It is needless to say that there should also be experiences that are negative lessons.

\section{Japanese Agriculture, Food and Trade Issues}

\section{1) Japan as a newly developed country}

Let us clarify the position of Japan as a developed country from an international bird's-eye view. Since actual situations of agriculture and food vary widely among developed countries, they could broadly be classified into two groups, namely, developed countries among EU members ${ }^{1)}$ and developed countries of European origin on new continents, that is, the United States, Canada, Australia and New Zealand. The first

\footnotetext{
${ }^{1}$ Fukushima University

r848@ipc.fukushima-u.ac.jp
} 
group developed earlier and the second later. The history reflects on their differences in farm land endowment, which basically determines their agricultural competitiveness.

Japan is a newly developed country, neither of first or second group. So far it has been the leading runner of economic development in Monsoon Asia. At the same time, there is a trend toward the birth of developed countries in this area that are different from the first and second group. This is the third group, and South Korea and Taiwan are already developed countries in the OECD context. ${ }^{2)}$

The author mentioned in the introduction that the experiences as a newly developed country may serve as good references for the agricultural trade issues of countries in Monsoon Asia. From this viewpoint, the next section summarizes Japan's experiences since the postwar economic growth era. If we go back to Japanese agricultural history of the Meiji Era, it may provide more lessons for least-developed countries that also exist in Asia. However, the author is not knowledgeable enough about prewar agricultural history to spread the wings of argument so widely.

\section{2) Japanese agriculture, food and society}

To understand Japan's position in the context of agricultural trade, it is appropriate to apply a two-step approach, that is, to confirm the situations of Japanese agriculture and food as the base and then uncover the characteristics of how Japan dealt with agricultural trade issues, especially, market-opening issues. As for Japanese agriculture and food, we will just confirm the main points which contain not only the characteristics common to Monsoon Asia but also characteristics unique to Japan. ${ }^{3)}$

Japanese agriculture cannot be discussed uniformly. On one hand, there is paddy farming in which cultivation by part-time farmers is the majority and aging of farmers is pronounced. On the other hand, the sectors like livestock farming and greenhouse horticulture have steadily expanded their size and farm management has been upgraded through incorporation and the introduction of employees. Land using agriculture in Hokkaido, including paddy farming, is dominated by full-time farmers and is different from the situation in the rest of Japan. For the regions with highly aged paddy farmers, it is possible to regard the conditions for structural reform as being ready, after the issue having been postponed for half a century.

Regarding Japanese food, consumption of animal protein, fat and oil has increased remarkably with postwar economic growth. The ingredient composition of Japanese diet dramatically changed, partly supported by mass imports of feed grains for livestock and soybeans for oil. Contrasted to this is the consumption of rice as the staple food. It has already decreased to less than half of its peak of $118 \mathrm{~kg}$ per capita in 1962 . At the same time, most items whose consumption had increased remarkably have already hit the ceiling and are in the declining phase. As for this transition, we should take into consideration factors like recent aging. However, based on Japan's postwar experiences, it may be possible to estimate future saturation level of food consumption of the regions where Asians are the major population.

Not only has ingredient composition changed, but also Japanese ways to purchase and eat food; that is, purchase of processed food and eating out have increased. According to the estimation by the Ministry of Agriculture, Forestry and Fisheries based on the 2011 Input Output Table, out of a total expenditure on food and drink of 76 billion yen, fresh food, processed food and eating out account for $16 \%, 51 \%$ and $33 \%$, respectively. From a different point of view, the food industry, which is composed of food processing, food distribution and eating out service, has expanded significantly. However, the dependence on processed food and eating out differs according to whether or not the households are single. Besides, in recent years, food expenditure level has varied significantly according to household income level. ${ }^{4)}$ As for Japanese eating habits, we could say that there is an increasing tendency of polarization both by household composition and income level.

While eating habits and agriculture have changed greatly with the general increase in the income level, there could also be changes in the themes which Japa-

1) Among 28 present member countries of EU, 6 countries are not included OECD. Definition of developed country varies among international organizations and OECD member countries might not be developed countries.

2) Taiwan is not OECD member country, but they participate in its activities as an observer. Taiwan's recent per capita income is $70 \%$ of that in Japan.

3) It may be too rough to discuss Monsoon Asia as one uniform area. There are differences among countries and, within a country, differences of agricultural areas with old history and newly developed ones. For this point, Hara (2013) is highly suggestive.

4) For the realities of Japan's eating habits from the viewpoint of age groups and income levels, Ishibashi (2006) and Kusakari's series of study (Kusakari, 2011, etc.) carried out interesting analysis. 
nese society is interested in. One of the changes is a spread of interest or concern over income disparity. Recently, the use of the phrase 'income gap' has clearly increased. Another change is a rising interest in byproducts and side effects that are transferred outside the market, that is, external economy and diseconomy. Regarding agriculture, multi-functional roles of agriculture have been referred to frequently. This is external economy which also has a characteristic of public goods with joint consumption and non-excludability. Using a theoretical model of interpretation, increase in income level has lowered marginal utility of goods and services purchased in the market and has raised marginal utility of byproducts and side effects transferred outside the market.

3) Framework of agricultural trade negotiations

The transition of issues postwar Japanese agriculture faced related to trade liberalization corresponded to the changing trends in global trade liberalization. Japan joined GATT in 1955, the year of the turning point from postwar recovery period to high economic growth era. After that, starting from the liberalization of 121 items such as rye and coffee beans in 1960, that is, removal of quantitative import restrictions, a considerable number of items had been liberalized by early 1970 s. $^{5)}$ Not only niche agricultural products, but also products that are familiar in the ordinary Japanese diet, like soybeans, onions, chicken, bananas, grapefruit and pork, were included. However, trade liberalization then didn't provoke a big political issue.

The whole situation changed after the United States requested the market opening of beef and oranges. Through the first negotiation in 1977 to the third one in 1988, expansion or removal of import quotas, tariffication and reduction of tariffs were agreed on. The issue of beef and oranges was apparently related to the trade friction over the sharp increase in Japan's export of automobiles and other manufactured goods, mass media such as newspaper and TV reported widely. Nevertheless, the form of negotiation persisted as a bilateral one on specific agricultural items. The Uruguay Round, started in 1986, fundamentally changed the structure of agricultural trade as it was a multilateral full-scaled negotiation covering both agricultural and non-agricultural products.

\section{Basic Theory of Economics on Trade}

\section{1) Inter-industry adjustment}

Economic views on international trade are diversi- fied even within those deemed classic. Two leading theorists of classical economics, Ricardo and Malthus, also had different views. While Ricardo supported a free trade theory that was based on comparative production cost, Malthus stayed on the opposite side regarding the elimination of the Corn Laws. As a criticism of simple free trade theory, there was an argument by Friedrich List based on a long-term view. He was a well-known historian in Germany, which was then a less-developed country. Although their arguments were different, what they had in common was that they did not focus on specific goods alone. Since today's trade negotiations cover various goods and services, pursuing multilateral agreements, it might be meaningful to go back to classical theory on trade.

One of the points of the classic proposition of free trade is the relation between industries with comparative advantage and those with comparative disadvantage. Under free trade, production factors move from disadvantaged industries to advantaged industries, and comparison between with and without trade shows that trade is beneficial for all countries concerned. In other words, it brings about Pareto improvement. However, most of the models in textbooks do not consider the cost of moving production factors between industries, that is, inter-industry adjustment cost. Or explanation is given on the implicit assumption that the increase in the total net profit is well above the adjustment cost caused by free trade.

In the real world, there should be many cases in which the inter-industry adjustment cost cannot be ignored. However, this point has not been sufficiently examined in postwar market opening issues concerning Japanese agricultural products. It is appropriate to understand that the option of scaling down agriculture as a disadvantaged industry was not explicitly proposed, at least in official places.

It could be said that successive Japanese governments had the policy, at least as their announced principle, to minimize trade liberalization of agricultural products and lessen the damage on domestic agriculture by adopting various measures against worsened competitive conditions due to the change in their border situation. Therefore, they have allocated policy resources for the areas of corresponding products, often with financial expenditure.

\section{2) Distribution adjustment between benefit and loss}

In regard to such situations, it would be useful to discuss relying on a more general framework of profit

5) 'Annual reports during last 50 years' attached to '2010 White paper on food, agriculture and rural areas' shows a brief summary of history of postwar import liberalization of agricultural products. 
re-distribution. More specifically, an examination using the framework of compensation principle by Kardor-Hicks is recommended. This is the standard of judgment whether to accept an institutional change when there are both people who gain profits and those who suffer losses. The change is acceptable if the compensation for the losses by re-distribution of additional profit brings about Pareto improvement. It is a very normal situation that an institutional change generates both areas that gain profit and those that suffer losses. However, the viewing angle required for the analysis of agricultural products is not so simple.

Although there is a basic structure of re-distribution between the farmers of the agricultural product of concern and the companies or regions that benefit from the free trade, the actual method of re-distribution would be through measures adopted by the government. Moreover, input of resources could be merely compensation in response to the loss of farmers or could be a way of strengthening measures for their long-term competitiveness. In the case of the latter, it is possible that the resources once allocated to the agricultural sector would be returned to consumers through price decline of the products with lower cost.

In addition, today's eating habits make the issue more complicated. While the food industry has become influential in the areas between agriculture and consumers' dining tables, price change in agricultural products cannot be reflected in retail food prices directly. In addition, as mentioned earlier, there is an increasing polarization of eating habits and therefore consumers cannot be treated in the same way. Moreover, as for influence on food processing industries, we should not discuss this in a unique way. There are cases that are located in rural areas and use domestic materials and cases that are located next to a large seaport and use imported materials.

As shown in the domestic situation regarding the Uruguay Round and TPP, recent discussions on Japanese agricultural trade have been heated prior to actual negotiations. The topic was frequently covered by general media like newspapers and TV, not to mention by agriculture-related media which took a stand against free trade. On the other hand, there have not been many ex-post-facto attempts to review the actual impacts of market opening. ${ }^{6)}$ The ex-post-facto assessment of the government's policy adopted in response to changes of border measures has not been highlighted, with a few exceptions of partial comments. Such a situation suggests the important subject of research which will look back on the past. Surely it is not an easy task. In impact assessment there is difficulty related to the common method of estimation, especially that of separation of changes by free trade-related events from those caused by the general domestic economic situation.

\section{Japanese Society Facing Agricultural Trade Issues}

\section{1) Third group of developed countries}

The author grouped developed countries into three types at the beginning of the second section. This grouping reflects their characteristics of import and export of agricultural products, especially basic food represented by cereals, namely, developed countries of new continents of European origin, which are the export side, making use of abundant land (second group), developed countries of the EU which maintain relatively high domestic production supported by longterm protection policy under the Common Agricultural Policy (first group), and newly developed Asian countries such as Japan and Korea, which import large quantities of food (third group).

Japan, so far the leading runner of newly developed Asian countries, experienced drastic changes in eating habits supported by imported food and livestock feed. Japan also has been requested to further open the market for agricultural products by developed countries of new continents, especially by the United States. The same structure can be found in Korea and Taiwan, whose self-sufficiency rate of cereals in 2013 were $25 \%$ and $20 \%$, respectively, which is below the $28 \%$ in Japan ('Self-sufficiency rate of cereals of foreign countries (2013) (trial calculation)' in 2016 Food Balance Sheet by MAFF).

Japan's import counterparts of agricultural products are not only developed countries like the United States. Japan imports from such countries as China, Thailand and Brazil, too. In a rather generalized way, it can be said that developed countries of the third group also face the issue of how to deal with requests for market opening raised by developing countries. The awareness of this issue was shared among many countries at the beginning of the Doha Round as it placed importance on issues of developing countries. However, viewpoints to criticize developed countries' protection policy for agriculture in connection with import of agricul-

6) As an ex-post examination for trade liberalization, there is an interesting document 'Impact assessment on past import liberalization' submitted on February 2007 by Ministry of Agriculture, Forestry and Fisheries to EPA agricultural working group at the Council on Economic and Fiscal Policy. From a long-term viewpoint, with domestic measures introduced in mind, it attempted to assess impacts on both consumption and production of four items: beef, citrus, apple and cherry. 
tural products by developed countries had already become an internationally common understanding just before the end of the Uruguay Round. Agenda 21 adopted in 'The United Nations Conference on Environment and Development' in 1992 included the following sentence:

In particular, the achievement of this objective requires that there be substantial and progressive reduction in the support and protection of agriculture - covering internal regimes, market access and export subsidies - as well as of industry and other sectors, in order to avoid inflicting large losses on the more efficient producers, especially in developing countries.

\section{2) Food security}

As the author pointed out, Japan has maintained a cautious attitude towards market opening of agricultural products. While there is a factor like the political power of agricultural organizations, there are also discussions on the positive meaning of maintaining domestic agricultural production from the viewpoint of Japanese society as a whole. Such discussions include some points which put brakes on simple free trade proposals based on the theory of comparative advantage. In other words, the points are not included in the framework of classic trade theory. While the contents of those points have been reflected in the arguments of successive Japanese governments, it is also important to once again examine their validity in the international context.

One of the points is the food security issue. Food is a highly selective good in a society like Japan, yet it is still an absolutely necessity, as human beings cannot maintain a healthy life without the minimum amount of it. Since food has two such aspects, it is the government's responsibility of the highest priority to provide systems under which people can secure the necessary amount of food under any circumstances. The author assumes here unexpected situations like international friction and serious natural disasters. One of the issues is to select carefully the specific contents necessary for food security in both quantity and quality and the application of a scheme of agricultural resources for this purpose. We know that these will be quite different from those in daily life where people enjoy highly selective and rich diets.

In the context of international validity, we should clarify the difference between the concept of food security which is discussed here and the concept of food security in general. This recognition is quite important for sending out a clear message abroad.
Food security exists when all people, at all times, have physical, social and economic access to sufficient, safe and nutritious food to meet their dietary needs and food preferences for an active and healthy life.

This is the definition of food security by the FAO, based on the agreement made in the World Food Summit (agreed at the World Food Summit in 1996 with an addition made at the summit in 2009). As plainly indicated in the world's distribution of undernourished people, food security is basically an issue of the daily diets of the poor in developing countries. At the same time, the definition by the FAO includes food security with which necessary food is available under unexpected contingencies. Food security in abnormal situations can be said to be the subset of food security as a general concept. Furthermore, not only is such a simple categorical clarification necessary, but it is also important to clarify concrete images of food insecurity and measures against it. ${ }^{7)}$ It may be one of the subjects of agricultural economic research.

As for food security in developed countries, due to the nature of the matter, it is important to acquire consensus from the international community, especially from neighbor countries. Developed countries in the third group are close to each other and there are commonalities that people depend on other countries for a large part of their food supply. It is necessary to mutually understand that food security is the basis that supports people's cool judgment and stable behavior. It is important to send out a message worldwide on the importance of food security of developed countries based on such a mutual understanding in neighboring countries.

In addition, if agricultural policy that preserves minimum necessary agricultural production or agricultural resources for food security is accepted internationally, it may be linked to the restriction on agricultural protection policy implemented beyond that level.

3) External economy of agricultural production

Another point of argument raised as a brake on simple free trade theory for agricultural products is the existence of an external economy. The term used in policy acknowledges the multi-functional roles of agriculture. In Japan the system of direct payment for hilly and mountainous areas was introduced in 2000 to preserve multi-functional roles. For agricultural byproducts with a public good character, we share some common understanding with early developed European

7) This may be one of Doha Round's points of dispute. Regarding procurement of official food stocks which India and other developing countries insist, careful examination is necessary as to how they assume impairment of food security. 
countries. It may also be possible to have positive discussions on the value of agricultural byproducts with Monsoon Asia, which has also long history of rural areas. At the same time, in the sense of market failure, it is necessary to keep in view the burdens on the environment, that is, the external diseconomy involved in agriculture.

How has the presence of external economy and diseconomy been dealt with in agricultural trade negotiations so far? As described in the WTO Agricultural Agreement at the Uruguay Round, issues of externalities have not been dealt with in a way that is directly reflected in the structure of border measures. However, the biggest characteristic of the Uruguay Round related to agriculture is that it imposed regulations on domestic policies (amber box). The purpose of the regulations is to control production-stimulating policy, which was recognized as the background of trade friction over agricultural products. Contrarily, the Agreement also listed policies which can be implemented by the decision of individual countries (green box). For instance, policy for handicapped areas and that for environmental preservation are left to member countries' discretion. Japan's direct payment for hilly and mountainous areas is also green box policy. ${ }^{8)}$

As for this theme, it is important to compare the WTO with the FTA and EPA. While cases of the FTA and EPA vary widely, it is common with the WTO that an agreement covers both agricultural and nonagricultural products. In EPA negotiations, a change in domestic regulations concerning business activities often becomes the focal point. However, so far, the case of a concrete agreement based on agricultural externality has never become their topic. This issue appears to have two aspects. One is that it may be regarded to have little meaning to set additional regulations as the WTO agricultural agreement is still effective for a wide range of countries. The other aspect is that even if the EPA agrees on some regulation that differs from the WTO agreement, its effectiveness is limited to specific countries under the treaty. There might also be producers who trade with countries outside the treaty in concern. The question is whether it is possible or not to impose rules on agricultural policy which uniformly regulate producers in the country. If possible, what form would it take? This question is worth brainstorming.

\section{Conclusion}

Economists whose object of analysis is market economy have a perception that correction for market failure is the role of government. While we have such an understanding for the society of a country, the appropriate institution to correct market failure in the international community is under question. The WTO agricultural agreement, though by an indirect method, had stepped into this area. On the other hand, we have to pay attention to the movement of international organizations other than the WTO. For the issue of external economy or diseconomy, there is the United Nations Framework Convention on Climate Change.

Today's developed countries, while at different levels, are concerned about the expansion of income gap and adopt policies in view of income re-distribution. Internationally, various forms of international cooperation support improvement for developing countries. The ILO, which aims to improve people's working conditions, will soon celebrate its 100th anniversary. However, the international community does not have a direct means to correct income gap between countries or regions. On this point, expansion of the FTA or EPA has aspects to be concerned about. We cannot deny the possibility that trade diversion effects between countries under treaty and those out of treaty will lead to an increase in the gap. We also have to consider the situation where there are countries or regions left out of the FTA and EPA. Although an ex-post-facto correction system of income disparity is difficult in the international community, the viewpoint is becoming increasingly important to provide a brake on trade circumstances that lead to a widening of the gap.

Market economy is not almighty. However, it is a very useful system. Such understanding is shared by many societies in developed countries. In other words, market economy is a system which we should utilize wisely. It may be expected to spread such a stance from a single country's economy to the economy of the global society.

\section{References}

Hara, Y. (2013) Asian Agriculture and Japanese Agriculture, Shosekikobo Hayama Publishing Company (in Japanese).

Ishibashi, K. (2006) Analysis of Food Consumption Structure in Household, Norintoukeikyoukai (in

8) For green box policies listed in annex 2 of the WTO agricultural agreement, chapter 9 of Shogenji (2006) shows a possible categorization, namely, provision of public goods related to enhancement of productivity, encouragement of structural adjustment and correction of market failure. Direct payment for hilly and mountainous areas is included in correction of market failure. 
Japanese) .

Kusakari, H. (2011) Modern Problem Food Consumption, Seeking Collaboration between Household and Agriculture, Japanese Journal of Rural
Economics 83 (3): 146-160 (in Japanese).

Shogenji, S. (2006) Reform of Agricultural Policy in Modern Japan, University of Tokyo Press (in Japanese). 